\title{
Labouring Feeling: Harry Holland's Political Emotions
}

\author{
DOUGAL MCNEILL
}

\begin{abstract}
Reading Harry Holland's literary works as an integral part of his political project and vision, this essay argues that greater attention be paid to the dissident, radical and revolutionary socialist currents shaping Labour's thought world in the pre-1935 period. Holland's socialist project, and its ambitions to shape new kinds of political subjects, had, I suggest, a wider resonance and is of greater contemporary interest than most historians have allowed. His poetry and literary works need restored to scholarly and political attention.
\end{abstract}

"A beginning," Edward Said wrote some years ago, "not only creates but is its own method because it has intention." Political parties shape their narratives with the care of novelists. When was Labour's starting point in New Zealand? 1916 makes this year its centenary but, in the party's self-imagination, 1935 and the promise of government is the preferred point of origin. Harry Holland, and the forces he led for close to twenty years, do not appear in the short history of the Party offered in its 2011 opening campaign video; Michael Joseph Savage and the state housing programmes of the 1930s and 1940s are, in the contemporary imagination, Labour's origin. ${ }^{2}$ Holland figures, at best, as John the Baptist to Savage's Jesus; most of the time, however, outside of professional historical circles, Labour's early years are carefully unremembered, the chaos and contention of its ideological formation removed from twenty-first century social democracy's narrative of origin and destiny.

Holland's death in November 1933 occurred, Barry Gustafson claims in his biography of Savage, "at an opportune time for the Labour Party,"3 eager as its leaders were to shed the party's associations with revolutionary socialism and to assume the mantle of responsible government. Their historians have been eager to share the task of making sure that Holland's good remains interred with his bones. He is figured as a man out-of-place, abnormal and eccentric to the natural course of the New Zealand Labour movement. At once excessively emotional and forbiddingly intellectual, the standard portrait of Holland borrows from and deploys tropes from the tradition of the fanatic, that coldly emotional figure who must be excluded from the realm of the political. Holland lacked, the Liberal MP Leonard Isitt claimed in a debate in the House in 1919, that "ring of humane interest in what he uttered" and was a "cold, callous, calculating political agitator." Jock Phillips contrasts the "warm humanitarian" Savage with Holland, the "Marxist, an intellectual more concerned with the larger socialist vision." 5 John A. Lee, in unpublished draft notes, remembered his colleague as "abnormally sensitive," while Michael Bassett and Michael King portray him as a "revivalist," "preaching" with "messianic zeal." ${ }^{\prime}$ 'Farrell, Holland's biographer and a master of the genre of vindictive hagiography, presents him as "rash and easily flustered," "not naturally complex but direct, an enthusiast." "Gustafson, for good measure, mixes the cold with the hot, offering a vision of Holland as both "a doctrinaire socialist" from the "minority intellectual force in the New Zealand Labour Party" who was "self-righteous and dogmatic" but also filled with "a poet's ability to evoke an emotional response." "Emotion, not intellectual persuasion" took Holland to socialism, in O'Farrell's view, and it retained "an essentially emotional basis" throughout his life. ${ }^{10}$ Whereas Savage, in the historiography, is safe, paternal, benign, Holland remains socialist, proletarian, perhaps Bolshevist. This lashing together of contradictory condemnations - charges of an excess of emotion coupled with disavowals of a chilling excess of intellect and reason-figures Holland as an Antipodean iteration of the fanatic, that figure who, in Alberto Toscano's terms, serves as an outer limit or border for political discussion 
proper, and who allows "the culturaliziation and psychologisation of politics under the aegis of fanaticism, and the concomitant definition of a liberal political norm." Fanaticism's "constitutive ambivalence," Toscano continues, "which in many ways renders it an unreliable concept, turns it into a strength when it comes to disqualifying or demonizing adversaries."11 When the accusation of fanaticism - as with O'Farrell's dismissal of the "lurid" and "rabid" "tiny group of fanatics and malcontents" Holland organised in his early years-is used, Toscano suggests,

to disqualify or reject certain modes of political behaviour or allegiance from the normalised and normalizing vantage-point of a liberalism at once gradual and eternal.... [I]t is often difficult to tell whether we are dealing with the refusal to allow other forms of life now separated from the political to trespass into its realm ... or whether the real problem is that of an excess of politics. ${ }^{12}$

Holland's excess in all directions - an excess of words, in his voluminous, relentless production of pamphlets and articles; an excess of politics itself, in his intellectual curiosity and revolutionary autodidactism; an excess of emotion and affective commitment - needs to be shorn from the narrative of Labour's "path to political independence" for that path to gain stability and sense. If the story of social democracy has a teleology - towards government, and, eventually, the various Third Ways of our own era - then Holland's political emotions can be read only as a failure, only as a warning sign for the path not taken, and never to be revisited. Gustafson's biographical sketch sets up this division well. For him, Holland was

A prolific pamphleteer[,] ... he represented a minority intellectual force in the New Zealand Labour Party opposed to the mainstream of New Zealand socialism, which was sentimental rather than intellectual, Christian rather than Marxist, anti-poverty rather than anti-capitalist. [He d]id possess a humanitarian outlook, though more the bitter voice of protest for an oppressed class than an evangelist preaching to the unconverted. $^{13}$

This is much too neat, and too tidy. It is also, as with all accounts, as much a recreation of an idealised or model Labour party as it is a sketch of historical actuality. Gustafson reads for the Christian traditions he wished to see emphasised and reclaimed, much as O'Farrell did for his own traditions and, in turn, as I do here for mine. In what follows I want to sketch some of the ways in which a reading of the Holland archive can undo these assumed divisions - between sentiment and intellect, Christianity and Marxism, alleviation and revolution-and offer us a richer, messier, more contradictory portrait of Labour's early years. Beginnings, for parties of government, need to indicate an end-point, and a "host of containment strategies" 14 have grown up in the last hundred years keeping this unruly material from serious view. Teleological readings - starting with the question of how Labour managed to take power and re-ordering material accordingly - miss roads not taken; whatever the final results, Holland's socialist thinking represents a current active in the Labour Party's culture and strategy through to the 1930s that had an audience and emotional purchase. Re-visiting this archive, and thinking with and through Holland's labour of feeling, helps to undo some of the mental divisions that have calcified and hardened in our own analysis, between Second and Third International thinking, say, between sentiment and ideas, between revolutionary ambition and reformist settlement. Other beginnings might come into view.

Holland's own life and activity before his arrival in New Zealand were quite astonishingly varied, and well outside the norms of what have come to be mapped as the main roads of Australasian socialism. Born to farming parents in Queanbeyan, early experiences as a print worker and convert to the Salvation Army left him with abiding interests in literary culture, journalism and spiritual questions, if not spiritual solutions. Radicalised by his own 
family's poverty, by the 1890s Holland was a leader in the extreme left wing of New South Wales' socialism, organising in the Australian Socialist League, the Industrial Workers of the World, and with the Active Service Brigade, a desperate direct-action body of unemployed workers. Jailed for sedition following his intervention in the Broken Hill dispute, widely criticised within the labour movement and without, Holland was already in middle age by the time he arrived in New Zealand, and with two decades' work in revolutionary socialist propaganda and organisation behind him. An established, self-confident and well-read figure, his arrival in New Zealand coincided, more or less, with that unprecedented rise in class struggle associated with the miners' battle at Waihi and the strikes of 1913. His local reputation made through his organising and journalistic work during these battles, he was the public figure most closely associated with the far left in New Zealand from then until his death twenty years later.

\section{Educating Desire}

Holland combined, across his roles in Australia and New Zealand, an astonishingly energetic journalistic career with his commitments as a political agitator and activist. As parliamentary leader of the Labour party and M.P. for Buller he continued to write extensively in the labour press on a range of historical and contemporary topics, producing articles and pamphlets on colonialism in Sāmoa, the Chinese revolution, the poetry of Robert Burns, the Marxian theory of value and a host of other topics. Holland's writings make clear the importance of this literary work to his political project. He wrote to a friend in 1918 of the Social Democratic Party as the "active propagandist party of Socialism" in Wellington and saw its course of lectures and educational work as vital to winning Labour to a socialist programme. ${ }^{15}$ If Labour aimed "for something grander and higher and better" 16 than the compromises and adaptations to reality of capitalist parties, and "all the logic, all the facts, all the ethics" 17 were with Labour at the same time as its share of the vote and its allegiance amongst the working class remained in the minority, then the question of education, of forming new political subjects interpolated by socialist appeals and sharing anti-capitalist values, becomes essential. He was, in this project, of course by no means the only exponent. Instead, Holland reached back to, reaffirmed and radicalised an educational current pioneered by the Socialist Party before 1913 in New Zealand and developed elsewhere.

The Labour movement could not have effective politics, Holland's approach suggested, without developing affective politics, without labouring feeling. Part of this would involve simple didactic and instructional work - as with Holland's articles and lectures explaining the Marxian theory of value - and at other times, it involved questions of colonialism and racial attitudes, agitation, political analysis and moral exhortation combined in pamphlets such as Samoa: a Story that Teems with Tragedy. ${ }^{18}$ Holland's literary work aimed to fuse intellectual response and emotional identification, to produce knowing subjects for socialist political projects. "It was necessary for the proletariat to be born for social reality to become fully conscious," Georg Lukács claimed in his History and Class Consciousness, written at the same time Holland was active. ${ }^{19}$ Holland's Antipodean variation on this project of forging proletarian consciousness through self-knowledge and organised self-activity involved weaving together historical, literary and political examples to show for his working-class audience models of intellectual emotion, or informed political commitment. Burns's greatness, Holland's unfinished biography suggests, came from his combination of cool-headed realism and passionate feeling. Burns remains, in Holland's terms, a figure of whom we find that

in everything he wrote there is the true ring of honesty and sincerity. In the realms of fancy he remains a realist, recording no fabulous woes, no hollow fantastic sentimentalities. The passion that is limned with masterly power has glowed in a living heart, the opinion he utters has arisen in his own understanding. He gives expression 
to what is in him not from any outward call of vanity or self-interest, but because his heart is full and he cannot remain silent. He learns in suffering what he teaches in song. ${ }^{20}$

Academic commentators are, in the main, baffled by this approach. Bassett and King describe Holland's progressive marginalisation as leaving him "free to write more and to indulge his interest" in Sāmoa. Gustafson sees Holland's energy and time in his last years as wasted on "reading and writing rather dull articles, pamphlets and books reviews" while O'Farrell, whose biography displays little interest in Holland's intellectual formation, reading, or writing, contrasts his literary activity unfavourably with "the demands of practical politics." 21 The philistinism of these comments, taken on their own terms, expresses very well the dominant, empiricist, anti-intellectual strain of Labour theory and organisation over the past eighty years. What relevance, in this tradition, might empire in the Pacific, working-class history, personal transformation, or the "masterly power" of experience tempered by reflection have to the socialism of the party of Nordmeyer or Douglas? ${ }^{22}$ But these were not Holland's terms, and were not always the terms of his audience. Five hundred people were turned away from a 1920 lecture Holland gave at Auckland Town Hall on "Ireland: Famines and Rebellions." Hundreds attended a similar lecture in Wellington some months after the Rising. Holland's writings on Ireland combined attention to the urgencies of the present rebellion with a narrative some seven hundred years in scope, convinced as he was that "public ignorance" was part of the problem shaping workers' emotional responses to Ireland. A "very large audience" at the Dunedin Art Gallery in 1921, local papers reported, received Holland's historical lecture "with loud applause." 23 The dominant historiographic account misses the energy of this intellectual formation and thought-world. ${ }^{24}$ Holland, John A. Lee noted in a diary entry, "appreciated that the fight was to build socialism, not to hold office"; his "inspiration was literary-cum-worker, whereas Nash is accountant-cum-Christian ... Holland was intellectual enough to be eternally a rebel." 25 The "literary-cum-worker" inspiration links Holland's New Zealand work with the international trend in socialist activism Geoff Eley describes as "making democracy social,"26 those militant currents between the organised Leninism of the new Communist Parties and the openly reformist ambitions of the increasingly respectable Labour and Social Democratic parties to manage capitalism. Holland, like Eugene Debs in the United States or John McLean in Scotland, figured education - tireless agitation, relentless exposition, literary elaborationas the central socialist strategy, part of, in Andrew Milner's phrase, "the open-ended experiment in the education of desire" that was these currents' legacy from more avowedly Utopian traditions. ${ }^{27}$ Burns, in Holland's account, offered the model for a political militant; he had a "throbbing love of mankind" that drove a "world-stirring voice." 28 Education kindled emotion; emotion drove intellect; intellect led to agitation. The affective took effect.

\section{Red Roses}

Verse - its production, circulation, and adaptation-played a special role in the kind of affective communities of socialist militants Holland sought to form. His own verse, collected in Red Roses on the Highways (1924), was advertised prominently in almost all of his pamphlets and publications. Others' poems - whether by canonical authors or lesser-known figures - are often quoted in his speeches and articles, and the circulation of verses - as with the exchange of poems celebrating the West Coast environment with constituents - helped emotionally to bind together groups of collaborators. ${ }^{29}$ Holland distinguished his own writings as "mere verse" from "true poetry," positioning himself as "content to talk with the versemakers in the valley," ${ }^{30}$ Ian Wedde describes Holland's poetry as braked by conventions and limited to "pious apostrophising." ${ }^{31}$ Whatever the strength of this criticism from the view of 
literary history, however, Holland's verse as a form of political intervention performed another task.

Verse, in the cultural networks intersecting with the working-class movement in which Holland's own writing was produced, performed the political task of fostering sets of identification. "The Mixer," author of the songs collected in the Transport Workers' Song Book (1926), interpolates his readers as good unionists, comparing them with "The Backbiter," "The Dope," "The Rat" and the "Borer from Within." 32 "Wobbly" poems from Industrial Workers of the World newspapers would have been familiar to Holland from his time in Sydney, and these castigate the "barren brain" of the "dullard" and the "ass," the non-militant worker "as merry as a victim on the rack" as they urge combative class independence. ${ }^{33}$ To this negative work of de-mystification, Holland's own verses - with their natural imagery of socialism coming when "the world's a-throb with the joy of life - / The Sun is on the hills" 34 - draw positive connections between political activity, earthly renewal and the workings of the earth itself, thus echoing in turn and renewing older rhetorical associations of socialism with "brighter times" and "new dawns." ${ }^{35}$ Working-class poets' work circulated in the political press - the Maoriland Worker above all, which also printed verse collections - and their works thus joined in implicit conversation with prose articles and accounts sharing their print space. This "Chartist poetics," to borrow Kirstie Blair's phrase, worked as a kind of emotional organisation, both collecting material from bourgeois or "high" culture for use - in the form of epigraphs, quotations, supplements - by the working-class movement, but also by providing a new rhetoric and chance for self-expression to strengthen socialism's internal coherence and community. ${ }^{36}$ Burns' role as "poet of the masses," Holland told the readers of the New Zealand Worker, and as "poet and revolutionist" is strongest when he "voices all the various moods of men." 37 The verses in Red Roses on the Highway shift accordingly from satirical (the patriot "waved a flag-AND STAYED AT HOME") to rhapsodic ("this is life!") to encouraging ("take heart"). ${ }^{38}$ Labouring feeling like this - agitating political emotion-follows the method suggested by the Australian poet and campaigner Bernard O'Dowd, whose Poetry Militant Holland will most probably have been familiar with from his intellectual and political circles in Sydney. "We cannot," O'Dowd argues,

push on a Cause, however we may be intellectually convinced of its rightness, and however we may be theoretically interested in it, unless we also vehemently desire its success, vehemently wish that its principles be adopted by the world. ${ }^{39}$

Verse, in this political environment, is not a retreat from politics but rather the pursuit of politics by other rhetorical means. O'Farrell and other historians, however, separate Holland's literary work - an embarrassing oddity for them-from his political life. Verse, for O'Farrell, is pathological, a symptom:

Holland, overwrought, despondent and ill, came to verse writing in the time of the defeat of his highest hopes. It gave him a great sense of release to pour out his yearnings, frustrations and protests in this way. On the one hand, verse writing allowed him to express the violent reactions which defeat and failure had built up within him; on the other, the world of the future he could create for himself gave that mystic sense of power and of hopeful certainty he needed. It is significant that Holland's verse writing continued from this time of defeat, until 1919, just after his success in the New Zealand Labour Party. ${ }^{40}$

Unpublished papers suggest O'Farrell is mistaken when he dates the end of Holland's writing with such finality. Whatever the truth of this, however, he misreads either way the public, political, directed role of verse in Holland's socialism. ${ }^{41}$ The private circulation of poemsand the interpretive work involved in reprinting and re-contextualising verse - allowed Holland 
to create networks of fellow feeling. With his Australian friend Josiah Cocking he shared verses, ideas about composition and technique, and political reports all mixed together in a varied correspondence. Cocking replied with verses of his own, and then some of these would be published in Australian socialist journals. Pre-war debates from their shared activity around the International Socialist Review in Sydney-when Holland published Cocking's verse contributions as "Dandelion"- could be revisited in the New Zealand Labour years to re-affirm old commitments. Cocking had, in his "Strike Breaker's Soliloquy," ventriloquized a scab calling Holland the figure who "all my tricks discloses; / He's the thorn among my roses." A dozen years later he would publish in The Industrialist a poem celebrating the project of forming "One Big Union" (1922):

One Mighty Union vile race-hatred spurns,

Seeing the vision of bold Bobby Burns;

Cannons all silent and war-flags all furled;

Nations one great brotherhood all over the world. ${ }^{42}$

Two years earlier Holland had replied to critics on his left that he stood "where I have ever stood - for one big union on the industrial field, and one big party on the political field, each with the revolutionary purpose of overthrowing Capitalism and writing victory for Socialism." ${ }^{33}$ The Maoriland Worker's printing company published J. B. Hulbert's My Garden and Other Verses (1922) — verses, Robert Hogg announced in his Preface, that were "no great shakes ... but [successful] as folk-song meant to hearten comrades in the rough and tumble of the proletarian fight for freedom" - and re-introduced into circulation poems from the 1890s Maritime dispute ("The Scab") and more songs "to chant the COMMON GOOD". ${ }^{44}$ Holland's verse, in this context, is another way of "writing victory for Socialism," and not a personal vent for frustration. O'Farrell, because he makes no attempt to imagine the vitality of this socialist tradition, cannot read its literary production on their own terms.

These political emotions were internationalist currents too, and Holland used quotation emotionally to reinforce the internationalist commitments of his revolutionary socialism. His anti-conscription poem "Maoriland to Australia" was reprinted from the Maoriland Worker by the Melbourne journal Labor's Call in 1916; circulating verse fostered internationalist political community. A poem by Charlotte Perkins Gilman, first published by him in the International Socialist Review in 1907, re-appears as a dedicatory verse sent to friends as a Christmas greeting in 1923. "Build the Ideal!." Gilman's poem runs, linking Holland's parliamentary and extra-parliamentary careers together as part of this project of the "education of desire." 45 Holland's Burns is a particularly internationalist poet, Scottish in origin and yet encouraging a love of humanity that embraces every type from the veriest vagrants to the noblest examples of manly worth, that embraces every nationality from the farthest east to the farthest west, and every breed from the Patagonian to the inscrutable Chinese; love of creation from the modest daisy and the timorous mouse to the most serviceable of man's companions and the most beautiful of man's surroundings. ${ }^{46}$

The inclusion of the "inscrutable Chinese" in this list is both literary flourish and political intervention in the notably Sinophobic culture of Australasian Labour.

Verse acts as emotional labour by serving, in Bernard O'Dowd's phrase, as "a living catalyst in the intellectual laboratory, ${ }^{, 47}$ preaching and exhorting for organisation:

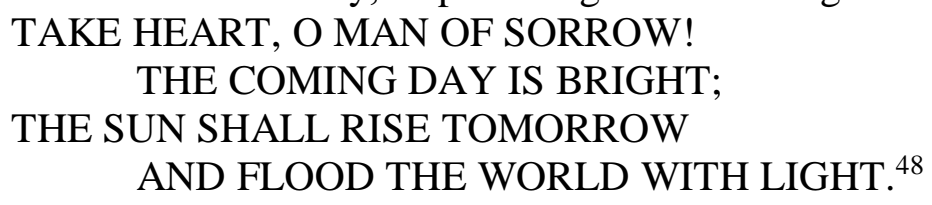




\section{Religious Feeling}

Gustafson separates Holland's Marxism from what he figures as the dominant Christian strain in New Zealand socialism. In fact, it was in his attempts to combine these two that Holland developed some of his most distinctive Utopian work of political emotion. Josiah Cocking's son remembered the two men as "Salvationist Socialists," and Holland's background in the Salvation Army left him with a life-long interest in religion and spirituality in general, and the life and teachings of Jesus Christ in particular. ${ }^{49}$ Holland's was not a "Christian Socialism" in the sense of R. H. Tawney's or Ramsay MacDonald's, but, rather, his ongoing interest in Christianity was part of his attempt to revolutionize emotional life and bring emotion into the realm of the revolutionary. He sent his children to Socialist Sunday Schools in both Australia and New Zealand, and the International Socialist Review in Sydney published regular features on Christian mythology from a materialist standpoint. Holland read left-wing Christian publications such as The Crusader throughout his life. ${ }^{50}$ Writing condolences to Cocking after his mother's death, Holland asked "does the acceptance of the materialist theory of history necessarily involve a disbelief in an after life? I think not." He went on to recommend Eugene V. Debs's article "Comrade and Equal," a socialist case for women's equality. ${ }^{51}$ Whereas some in the Marxian Society insisted that "a Christian cannot be a Socialist" and that the choice was, in Moses Baritz's terms, "Jesus Christ or Karl Marx?," Holland argued that Jesus Christ was the "Red Fed par excellence" and that he stood for Communism, Republicanism, Industrial Democracy and National Freedom. ${ }^{52}$

Holland recognised the emotional and affective power of religion, the "protest against real suffering" and the "sigh of the oppressed creature," as Marx described it, and his writings and activity across his career, from his political attacks on the sectarian Protestant Political Association to his literary responses to the Bible and Judaeo-Christian mythology reflect a strategic orientation as much as a personal interest. ${ }^{53}$ Holland lectured on "the strike that Moses led and won" and drew on Christian thought and imagery across his entire career. ${ }^{54}$ Christian belief provided the spiritual and emotional vocabulary for the Australasian working class, and so it would be folly for any party trying to win the loyalty of that class to scorn its emotional coherence and appeal. Holland's writings on Burns presented his satirical verse as "directed in the main against the hollowness and sham of the ceremonial and the intolerance and tyranny of clerical administration; they were never directed against religion or its sincere votaries"; the rhetorical aim here is to split religious feeling from the anti-Labour forces of organised religion. ${ }^{55}$ In advancing this approach, Holland acted within the mainstream of international socialism. Lenin also insisted that the Bolsheviks be "absolutely opposed to giving the slightest offence to [workers'] religious convictions," mocking "infant-school materialists," while Trotsky insisted that "the Psalmist" could "speak to our soul" like Byron or Shakespeare. ${ }^{56}$ For the socialist intellectual currents Holland worked within and led, this revolutionary evocation of Christianity served both as a way to try and win workers to militant anti-capitalism, and as a way of using old rhetoric for new ends. Thus Philip Bliss's popular hymn "Dare to be a Daniel" (1873) is re-written by Hulbert: "If privilege and power you taunt / You're not the sort of Daniel that they want." O'Dowd remembers "a fragment" of the hymn heard "while passing a Ballarat street preacher's meeting" as "the whole seven gifts of the Holy Spirit to me in my own [socialist] pilgrimage thus far!" 57 Edward Hunter's "Song of Freedom" (1914) blends the internationalist community-building of socialist verse-work with the emotional labour of materialist evocations of religion. Dedicated to Mother Jones, Jim Larkin and Holland, it attempts to create a new place for Christian myth in the tradition of the oppressed: 
See Spartacus and Jesus, Emmett, Danton, Holland, yea -

The Spirit of the Poor cries loud, the outcasts call for Right,

The dripping scaffold waves the banner of the Dawn of Day;

And Liberty comes pressing on, 'neath shackles forged by Might. ${ }^{58}$

Hunter, in his poetic identity as Billy Banjo, worked in a similar literary-political field to Holland. Eileen Duggan's memorial at Holland's death, then, a poem comparing Holland's class anger to "a mood of Christ's," 59 fits a longer tradition, whatever her own affiliations, of socialist intervention in religious thought and feeling.

\section{Conclusions}

Why does this matter? Holland was, after all, marginalised, and the tradition of socialist organisation he upheld puttered out in New Zealand much as it did across the rest of the Anglosphere. Savage's party shone where Holland's faded. What is there worth remembering in this archive?

Reading Holland's literary work with a view to approaching it on its own terms brings back into focus some of the complicated, contested, intertwining intellectual strands in the weave of Labour thinking. His literary connections, drawing him into a network from Napier to Newcastle, Greytown to Glasgow, remind us of the ongoing energy of trans-Tasman and international socialist networks and streams of ideas, publications, and strategies. Utopian politics returns to our attention. James O'Brien, one of Holland's comrades in the Grey River Argus and by 1933 an M.P, remembered him at his death as a figure who "ranks with Keir Hardie, Jean Jaures, Karl Liebknecht and other stalwarts of the past." 60 The incongruity of that trio is revealing: the pacifist Labour figure Hardie; the Social Democrat Jaures; the Communist Liebknecht. That, just two years before the first Labour government took office, such contradictory figures could be referred to for tradition in a Labour publication indicates the breadth and energy of the party's thought-world. Holland's fusion of emotional appeal and materialist reason, his literary evocation and political calculation, his straddling of revolutionary demands and reformist organisation; all this makes more sense when considered as part of an organisation and project still in movement. Janet Fraser remembered him referring to Edward Bellamy's Utopian novel Looking Backward along with Marx's Capital as his two primary influences. ${ }^{61}$ This Utopian element has been downplayed by both the dominant trend in Labour history, fixated as it is on the party's path to "political independence" and realism, and by Communist currents, arguing as they did, with Engels, that Utopian thought was "the socialism of earlier days." 62 Holland's labouring feeling - too left-wing for his colleagues in Labour's leadership; too broad-based for the new proponents of Leninism-supports Verity Burgmann's contention that, in Australasia, Utopian demands flourished at precisely those moments when, in the classical Marxist scheme, they ought to have been extinguished. ${ }^{63}$ Holland's work re-affirms the place of conflict, contestation, and ideas in Labour's formation and in political history. The sea-change, in most accounts, happened in reverse: our job now, with this archive, is to point to what might once again become rich and strange, and to return some of the messiness and excitement of strategies unpursued to the too narrowly teleological story too often told.

After all, "beginning," Edward Said suggests, "ultimately implies return and repetition rather than simple linear accomplishment." their pasts some vision of their possible future. If Holland's historical marginalisation is 
symptomatic of problems in Labour's account of itself now, his rediscovery might offer futures and possibilities for labour elsewhere.

\footnotetext{
${ }^{1}$ Edward Said, Beginnings: Intention and Method (New York: Columbia University Press, 1975), xiii.

${ }^{2}$ The campaign video, itself a remarkable piece of historical reconstruction and narrative, can be viewed at https://www.youtube.com/watch?v=MN5DZC4MimQ. The Party's current website, in an act of equal opportunity historical selection, contains no historical material at all.

${ }^{3}$ Barry Gustafson, From the Cradle to the Grave: A Biography of Michael Joseph Savage (Auckland: Reed Methuen, 1986), 270.

${ }^{4}$ Quoted in P. J. O'Farrell, Harry Holland: Militant Socialist (Canberra: ANU Press, 1964), 104.

${ }^{5}$ Jock Phillips, "Remembering Labour Dead: the Memorials to Harry Holland and Micky Savage," in Culture and the Labour Movement, ed. John E. Martin and Kerry Taylors (Palmerston North:

Dunmore Press 1991), 246.

${ }^{6}$ John A. Lee, draft memorial article, now held in the Lee papers, ATL MS-Papers-7973-3.

${ }^{7}$ Michael Bassett with Michael King, Tomorrow Comes the Song: A Life of Peter Fraser (Auckland: Penguin, 2000), 80, 89, 109.

${ }^{8}$ O'Farrell, Harry Holland, 96, 138.

${ }^{9}$ Barry Gustafson, Labour's Path to Political Independence (Auckland: Oxford University Press, 1980), 158, 65-6.

${ }^{10}$ O'Farrell, p. 5.

${ }^{11}$ Alberto Toscano, Fanaticism: On the Uses of an Idea (London: Verso, 2010), 149, 249.

${ }^{12}$ O'Farrell, 8; Toscano, xxi-xxii.

${ }^{13}$ Gustafson, Labour's Path, 158.

${ }^{14}$ Fredric Jameson, The Political Unconscious: Narrative as a Socially Symbolic Act (Ithaca: Cornell University Press, 1982), 181.

${ }^{15}$ Holland to Josiah Cocking, 18 June, 1918. Letter transcribed in Cocking's personal papers:

Notebook Diary E (1909-1920), Cultural Collections, University of Newcastle, 161.

${ }^{16}$ Labour and the Fusion. Should Labour Have Joined the National Cabinet? Debated by John Payne and H. E. Holland (Wellington: Maoriland Worker Printery, 1915), 6.

${ }^{17}$ Holland to Cocking, quoted in O'Farrell, 80.

${ }^{18}$ On Marxian theories of value: Maoriland Worker, $17^{\text {th }}$ November 1915, 7; Holland, The Marxian

Theory of Value: a Lecture First Delivered at Wellington College (Wellington: Grey River Argus

Company, 1921). On Sāmoa: Holland, Samoa: A Story that Teems with Tragedy (Wellington:

Maoriland Worker Printery, 1918). Holland's racial views were complex; if he was at the extreme anti-racist wing of the Australasian movement in many respects, in others his views were shaped by the prevailing racial imagination of the time. There is not the space here to explore this properly, and so for now see Cybèle Locke, "Solidarity Across the 'Colour' Line?" NZJH 42 no. 2 (2014): 50-70, and Nicholas Hoare, "New Zealand's 'Critics of Empire': Domestic Opposition to New Zealand's Pacific Empire, 1883-1948," MA Thesis, VUW, 2014.

${ }^{19}$ Georg Lukács, History and Class Consciousness: Studies in Marxist Dialectics, trans. R. Livingstone (London: Merlin Press, 1971), 19.

${ }^{20}$ AU NBAC P5, H. E. Holland Collection, Noel Butlin Archive, Australian National University.

${ }^{21}$ Bassett and King, 118; Gustafson, From the Cradle to the Grave, 135; O'Farrell, 99.

${ }^{22}$ On this see Nicholas Hoare, "Harry Holland's Samoan Complex," Journal of Pacific History 49, no. 2 (2014): 151-69.

${ }^{23}$ See R. P. Davis, “The New Zealand Labour Party's ‘Irish Campaign,' 1916-1921,” Political Science 19, no. 2 (1967): 13-23.

${ }^{24}$ It is one measure of the dominance of anti-intellectual trends that O'Farrell's biography, a sustained attack on its subject, remains the only book-length study and thus the standard source.

${ }^{25}$ Entries dated 27 June and 26 July, 1938, in John A. Lee, Diaries 1936-1940 (Christchurch:

Whitcoulls, 1981), 77, 84 .
} 
${ }^{26}$ Geoff Eley, Forging Democracy: the History of the Left in Europe 1850-2000 (Oxford: Oxford University Press, 2002), part 1.

${ }^{27}$ Andrew Milner, "Socialism, Utopian and Scientific?" Arena 31 (2008): 17.

${ }^{28}$ Holland papers, ANU.

${ }^{29}$ These poems are now held together in the Seddon family papers, ATL MS-Papers-1619-222.

${ }^{30}$ Preface to Red Roses on the Highways (Sydney: Holland and Stephenson, 1924).

${ }^{31}$ Ian Wedde, "Introduction" to The Penguin Book of New Zealand Verse (Auckland: Penguin, 1986).

32 "The Mixer," The Transport Workers' Song Book, Wellington, 1926. "The Mixer" was Henry Kirk, secretary of the Watersiders' Union in Greymouth. See Carol Dawber, "Voices of the West Coast" (PhD Thesis, University of Canterbury, 2012), 23-4.

${ }^{33}$ Fanning Discontent's Flame: Australian Wobbly Poetry (Albury: Corrosive Press, 2007), 3, 9, 11.

34 "Socialism," Red Roses, 50.

${ }^{35}$ The phrases are from a letter to the editor of the Maoriland Worker, discussing Holland (11 December, 1918), 2.

${ }^{36}$ See Kirstie Blair, "Let the Nightingales Alone: Correspondence Columns, the Scottish Press, and the Making of the Working-Class Poet," Victorian Periodical Review 47, no. 2 (2014): 190.

${ }^{37}$ Harry Holland, "Robert Burns: Poet and Revolutionist," New Zealand Worker, 27 January, 1926.

${ }^{38}$ Red Roses, 70, 71, 31.

${ }^{39}$ Bernard O'Dowd, Poetry Militant: An Australian Plea for the Poetry of Purpose (Melbourne: T. C. Lothian, 1909), 31. O'Dowd was the editor of the Melbourne socialist newspaper The Tocsin when Holland was editing the International Socialist, and they shared common allies and companions in Tom Mann and others. Although I have found no direct evidence Holland read O'Dowd's book, it was undoubtedly part of his general political and literary atmosphere.

${ }^{40}$ O'Farrell, 43.

${ }^{41}$ See, for example, "Watchman, what of the night?" in ATL MS-Papers-1815-06. Holland published a Christmas verse, "Peace on Earth" in the Grey River Argus, 24 December, 1920.

42 "Dandelion," "The Strike-Breaker's Soliloquy," International Socialist Review, Sydney, 26

February, 1910; "Daisy," "One Mighty Union," Industrialist 18 May, 1922. Holland had written to Cocking describing the first time he wrote verse, and discussing verse techniques, on 7th November 1911; the letter is reproduced in the Cocking Papers, Notebook E, 83.

${ }^{43}$ Quoted in Moses Baritz vs. H. E. Holland (Petone: Marxian Association, 1920), 6.

${ }^{44}$ J. B. Hulbert, My Garden and Other Verses (Wellington: Marxian Association, 1922), 11.

${ }^{45}$ See International Socialist Review 7 December, 1907, Cocking Papers, Notebook G, 107.

${ }^{46}$ Holland Papers, ANU.

${ }^{47}$ O’Dowd, 16.

48 "Take Heart," Red Roses, 31.

${ }^{49}$ Quoted in Melanie Nolan, "Personalizing Class Conflict Across the Tasman: the New Zealand Great Strike and Trans-Tasman Biography," JNZS 18 (2014): 128-29.

${ }^{50}$ The International Socialists also organised Christmas tree festivities; see, for example, International Socialist Review 19 December, 1907. The clippings filed in Holland's papers at the Turnbullcontaining Communist papers, Christian articles, independent socialist publications and more from across the world — give some sense of his eclectic range: ATL MS-Papers-1815-11.

${ }^{51}$ Cocking papers, Notebook D, 1910, 164.

${ }^{52}$ Holland, ATL MS-Papers-1815-06, undated speaker's notes; advertised lecture titles from Moses Baritz vs. H.E. Holland, 10.

${ }^{53}$ Karl Marx, Contribution to the Critique of Hegel's Philosophy of Right (Cambridge: Cambridge University Press, 1977), 131.

${ }^{54}$ See an Auckland Star report on this lecture, 27 March, 1913, 4, and the draft pamphlet held with the Holland papers, ATL MS-Papers-1815-06.

${ }_{55}^{55}$ Holland Papers, ANU.

${ }^{56}$ Lenin, "The Attitude of the Workers' Party to Religion" (1909), Collected Works (Moscow: Progress Publishers, 1971), vol. 15, 411; Leon Trotsky, "Class and Art" (1924) in On Literature and Art (New York: Monad Press, 1970), 66.

${ }^{57}$ Hulbert, My Garden, 14; O’Dowd, 39.

${ }^{58}$ Maoriland Worker, 22 July, 1914, 1.

Journal of New Zealand Studies NS21 (2015), 2-12 
${ }^{59}$ Eileen Duggan, “A Leader Pases," New Zealand Worker, 8 November, 1933.

${ }^{60}$ New Zealand Worker, 8 November 1933, 27.

${ }^{61}$ Janet Fraser, “A Famous Man I Knew: Harry Holland," 2YA broadcast, 22 April, 1937, ATL qMS0811. On Bellamy's reception in New Zealand socialism see Dougal McNeill, "Reading Nowhere in Erewhon: Bellamy, Morris, and New Zealand," Kōtare (2014): 1-13.

${ }^{62}$ Frederick Engels, Socialism: Utopian and Scientific (New York: International Publishers, 1935), 52.

${ }^{63}$ See her "Refuting Marx and Engels: Australian Utopianism in the 1890s," Arena 31 (2008): 21-45.

${ }^{64}$ Said, xiii. 